Available online at http://journal.stkip-andi-matappa.ac.id/index.php/histogram/index

Histogram: Jurnal Pendidikan Matematika 4(2)., 2020, 527 - 537

\title{
ANALISIS HASIL BELAJAR BERDASARKAN KOMPONEN PROSES LITERASI MATEMATIKA
}

\author{
Rusmining ${ }^{\text {* }}$ \\ ${ }^{1}$ Universitas Ahmad Dahlan
}

* Corresponding Author. Email: rusmining@pmat.uad.ac.id

Received: 10 Agustus 2020; Revised: 15 September 2020; Accepted: 30 September 2020

\section{ABSTRAK}

Penelitian ini merupakan penelitian kualitatif deskriptif, dengan tujuan untuk mendeskripsikan hasil belajar matematika dilihat berdasarkan komponen proses literasi matematika. Komponen proses merupakan salah satu dari tiga komponen penilaian menurut Program International Student Assesment (PISA). Komponen proses yang diuji dalam penelitian ini meliputi: (1) kemampuan merumuskan masalah, (2) kemampuan dalam menggunakan konsep, fakta, prosedur dan penalaran, dan (3) kemampuan menafsirkan hasil. Metode yang digunakan meliputi metode dokumentasi, observasi, dan wawancara, dengan triangulasi teknik digunakan sebagai cara menguji keabsahan data. Adapun hasil dari penelitian kualitatif deskriptif ini adalah (1) Kemampuan literasi ditinjau dari proses merumuskan masalah memperoleh skor rata-rata 23,33 dari skor maksimal 25 artinya mahasiswa sudah baik dalam merumuskan masalah yang disajikan pada soal.(2) Kemampuan literasi ditinjau dari proses menggunakan konsep, fakta, prosedur dan penalaran mendapatkan skor rata-rata 30,63 dari skor maksimal 50 artinya mahasiswa belum sepenuhnya mampu menggunakan kemampuan konsep, prosedur dengan baik. (3) Kemampuan literasi ditinjau dari proses melakukan penafsiran hasil mendapatkan skor rata-rata 15,73 dari skor maksimal 25 artinya mahasiswa belum sepenuhnya mampu menafsirkan dan mengevaluasi hasil pekerjaannya dengan benar. Dari ketiga komponen proses tersebut, dapat dikatakan bahwa kemampuan merumuskan masalah paling menonjol dibandingkan dengan dua kemampuan proses yang lain.

Kata Kunci: Komponen Proses, Literasi Matematika

\begin{abstract}
This research is a descriptive qualitative research, with aims to describe the learning outcomes of mathematics based on the process components of the mathematical literacy. Process components are one of three components of assessment according to the International Student Assessment Program (PISA). The process components tested in this study include (1) ability to formulate problems, (2) ability to use concepts, facts, procedures and reasoning, and (3) ability to interpret results. The method used includes of documentation, observation, and interviews, with triangulation techniques used as validity data. The results of this descriptive qualitative study are: (1) literacy ability in process of formulating problem obtains with average score of 23,33 from 25 maximum score. Its means the students are good at formulating the problems presented in the question. (2) Literacy ability of using concepts, facts, procedures and reasoning gets 30,63 average score from 50 maximum score. Its means students are not fully able to use conceptual skills, procedures properly. (3) Literacy ability in interpreting the results gets 15,73 average score from 25 maximum score. Its means the students are not fully able to interpret and evaluate the results of their work correctly. Among of the three process components, the conclution is the ability to formulate problems is most prominent compared to other process capabilities.
\end{abstract}

Keywords: Process Components, Mathematics Literacy

How to Cite: Rusmining. (2020). Analisis Hasil Belajar Berdasarkan Komponen Proses Literasi Matematika. Histogram: Jurnal Pendidikan Matematika, 4(2), 527 - 537, doi: http://dx.doi.org/10.31100/histogram.v4i2.726

Permalink/DOI: http://dx.doi.org/10.31100/histogram.v4i2.726

Copyright(C) 2020, THE AUTHOR (S). This article distributed under the CC-BY-SA-license. 


\section{Histogram: Jurnal Pendidikan Matematika, 4 (2), 2020 - 529 \\ Rusmining ${ }^{*}$}

\section{PENDAHULUAN}

Aljabar Linier termasuk bagian dari matakuliah wajib mahasiswa semester tiga. Matakuliah ini disusun sebagai lanjutan dari matakuliah aljabar elementer dan aljabar matriks yang merupakan matakuliah wajib pada semester sebelumnya. Salah satu kajian pada matakuliah aljabar linier yaitu ruang vektor. Berdasarkan hasil observasi dan wawancara, hasil belajar mahasiswa matakuliah aljabar linier menunjukkan hasil kurang optimal. Mahasiswa masih kesulitan saat dihadapkan dengan soal-soal yang berkaitan dengan penalaran dan pemecahan masalah.

Salah satu ciri dari matakuliah aljabar linier yaitu mahasiswa dituntut mampu menyelesaikan persoalan-persoalan matematika melalui proses yang sistematis serta benar. Proses yang sistematis berkaitan dengan pembuktian yang melibatkan berbagai aksioma, misal saat mahasiswa dituntut untuk membuktikan sebuah ruang vektor maka mahasiswa harus mampu membuktikan kebenarannya melalui sepuluh aksioma pada ruang vektor tersebut, sedangkan proses yang benar berkaitan dengan hasil akhir pembuktian (Draper, 2002). Hal ini sesuai dengan penilaian pada PISA yang lebih banyak mengukur kemampuan literasi matematika yang meliputi kemampuan penalaran, argumentasi dan pemecahan masalah (Ojose, 2011) \& (Wong, 2005).

Salah satu karakteristik soal pada PISA adalah substansi persoalan yang bersifat realistis dan kontekstual, memerlukan adanya penalaran dan penguatan argumentasi serta adanya kreativitas untuk menyelesaikan permasalahan tersebut (Brewley, 2012). Dengan demikian, karakteristik ini sesuai dengan ciri pembelajaran matematika di perguruan tinggi yaitu menuntut adanya proses yang sistematis dan benar dalam menyelesaikan suatu permasalahan.

Tiga komponen dalam studi PISA meliputi komponen konten, proses, dan konteks. Komponen konten didefinisikan sebagai isi atau bahan materi atau subjek matematika yang sedang dikaji meliputi geometri, aljabar, bilangan, serta statistik. Komponen proses didefinisikan sebagai tahapan-tahapan dalam menyelesaikan persoalan atau permasalahan dimana matematika digunakan sebagai cara atau alat untuk memecahkan persoalan tersebut. Komponen konteks diartikan sebagai kondisi dari suatu permasalahan yang dihadapi yang meliputi konteks pribadi, pendidikan, sosial, dan keilmuan (OECD, 2010). Pada studi PISA, sub komponen proses yang diuji meliputi: (1) Kemampuan dalam merumuskan masalah (Skor 25\%); (2) Kemampuan dalam 


\section{Histogram: Jurnal Pendidikan Matematika, 4 (2), 2020 - 530 \\ Rusmining $^{1^{*}}$}

menggunakan konsep, fakta, prosedur, dan penalaran (Skor 50\%); (3) Kemampuan dalam menafsirkan, menerapkan dan mengevaluasi hasil (Skor 25\%).

Permasalahan yang sering diungkap dalam pembelajaran matematika diantaranya tentang pembelajaran yang melibatkan konsep dan prosedur. Sejauh ini pembelajaran dianggap kurang memberikan kepercayaan kepada mahasiswa untuk berpikir kreatif dan kritis dalam menemukan solusi permasalahan yang diberikan (Lasati, 2007). Oleh karena itu, dosen harus mampu menghadirkan kesempatan kepada mahasiswa untuk belajar secara utuh dan menyeluruh yang meliputi pembelajaran konsep sampai dengan kreativitas dalam pemecahan masalah.

Kegiatan evaluasi merupakan hal yang tidak bisa terlepas dari proses pembelajaran. Dosen harus mampu menghadirkan instrumen evaluasi yang tepat artinya mampu menguji keberhasilan suatu proses pembelajaran secara valid. sen hendaknya tidak sekedar menilai hasil akhir pekerjaan mahasiswa, akan tetapi melihat dan menilai proses pengerjaan selama mahasiswa menyelesaikan permasalahan yang diberikan. Oleh karena itu, komponen proses literasi matematika menjadi salah satu cara penilaian yang bisa digunakan untuk mengukur proses belajar.

Adapun rumusan masalah yang diambil penelitian ini adalah bagaimana analisis dari hasil belajar matematika yang dilihat berdasarkan komponen proses literasi matematika. Sedangkan tujuan dari penelitian ini yakni mendeskripsikan hasil belajar matematika ditinjau berdasarkan komponen proses literasi matematika pada matakuliah aljabar linier. Kemudian manfaat dari adanya penelitian ini diantaranya: 1) melatih mahasiswa berpikir sistematis, kritis dan kreatif dalam menyelesaikan soal-soal pemecahan masalah, dan 2) memberikan gambaran secara deskriptif tentang kemampuan proses literasi matematika pada matakuliah aljabar linier yang selanjutnya bisa digunakan sebagai evaluasi dan perbaikan proses pembelajaran.

Penelitian ini diawali daripada penelitian-penelitian relevan tentang literasi matematika pada tahun-tahun sebelumnya yaitu: 1) penelitian tahun 2014 tentang pembelajaran konstruktivisme, literasi matematika dan pendidikan karakter, 2) penelitian tahun 2017 tentang komponen konten literasi matematika, dan 3) penelitian tahun 2018 tentang komponen konteks literasi matematika (Rusmining, 2017), serta penelitian pada tahun 2019 tentang literasi matematika mampu meningkatkan kemampuan komunikasi matematika (Rusmining, 2019). 


\section{Histogram: Jurnal Pendidikan Matematika, 4 (2), 2020 - 531 \\ Rusmining $^{1^{*}}$}

\section{METODE PENELITIAN}

Berdasarkan pada uraian bagian pendahuluan sebelumnya, maka dapat dikatakan bahwa penelitian ini dikelompokkan ke dalam penelitian kualitatif deskriptif. Adapun beberapa pertimbangan yang dipakai diantaranya: 1) penelitian ini berkaitan dengan pendeskripsian hasil belajar matematika dilihat berdasarakan komponen proses literasi matematika, 2) penelitian lebih bersifat induktif, dimana peneliti berupaya untuk mendeskripsikan hasil penelitian yang didapatkan dan terbuka untuk penelitian-penelitian sejenis selanjutnya, 3) penelitian dilakukan dalam situasi yang lugas, apa adanya, tanpa perlakuan khusus serta mengutamakan data yang bersifat kualitatif deskriptif (Sugiyono, 2010). Penelitian dilaksanakan kurang lebih selama 7 minggu atau setelah ujian tengah semester dengan cara melakukan pengamatan dan wawancara selama perkuliahan berjalan. Adapun subjek penelitian adalah mahasiswa semester tiga kelas $\mathrm{C}$ matakuliah Aljabar Linier sebanyak tiga puluh mahasiswa. Data diambil dari hasil tes tertulis, kemudian dianalisis berdasar sistematika pengerjaan dan ketentuan penskoran pada komponen proses literasi matematika.

Penelitian ini mendeskripsikan hasil belajar matematika dilihat berdasarkan komponen proses literasi matematika pada matakuliah aljabar linier dengan pokok bahasan ruang vektor. Adapun komponen penilaian yang dilihat meliputi: (1) Kemampuan mahasiswa dalam merumuskan masalah, dinilai dengan bobot skor 25\%; (2) Kemampuan mahasiswa dalam menggunakan konsep, fakta, prosedur dan penalaran, dinilai dengan bobot skor 50\%; (3) Kemampuan mahasiswa dalam menafsirkan hasil, dinilai dengan bobot skor 25\% (OECD, 2010).

\section{HASILDAN PEMBAHASAN}

Data hasil belajar matematika pada matakuliah Aljabar Linier dengan materi Ruang Vektor dianalisis berdasarkan urutan pada komponen proses literasi matematika, yang selanjutnya ditunjukkan pada Tabel 1 berikut.

Tabel 1. Hasil Belajar Matematika

\begin{tabular}{llcccc}
\hline & & \multicolumn{3}{c}{ Skor } & Nor \\
\cline { 2 - 5 } No & Mahasiswa & $\begin{array}{c}\text { Kemampuan } \\
\text { Merumuskan } \\
\text { Masalah }\end{array}$ & $\begin{array}{c}\text { Kemampuan } \\
\text { Menggunakan Fakta, } \\
\text { Konsep, Prosedur, } \\
\text { Penalaran }\end{array}$ & $\begin{array}{c}\text { Kemampuan } \\
\text { Menafsirkan } \\
\text { Hasil }\end{array}$ & Nilai \\
\hline 1 & Mhs-01 & 20 & 40 & 10 & 70 \\
\hline
\end{tabular}


Histogram: Jurnal Pendidikan Matematika, 4 (2), 2020 - 532 Rusmining $^{1^{*}}$

\begin{tabular}{|c|c|c|c|c|c|}
\hline \multirow[b]{2}{*}{ No } & \multirow[b]{2}{*}{ Mahasiswa } & \multicolumn{3}{|c|}{ Skor } & \multirow[b]{2}{*}{ Nilai } \\
\hline & & $\begin{array}{l}\text { Kemampuan } \\
\text { Merumuskan } \\
\text { Masalah }\end{array}$ & $\begin{array}{c}\text { Kemampuan } \\
\text { Menggunakan Fakta, } \\
\text { Konsep, Prosedur, } \\
\text { Penalaran }\end{array}$ & $\begin{array}{c}\text { Kemampuan } \\
\text { Menafsirkan } \\
\text { Hasil }\end{array}$ & \\
\hline 2 & Mhs-02 & 25 & 48 & 25 & 98 \\
\hline 3 & Mhs-03 & 20 & 0 & 0 & 20 \\
\hline 4 & Mhs-04 & 20 & 13 & 10 & 43 \\
\hline 5 & Mhs-05 & 20 & 3 & 0 & 23 \\
\hline 6 & Mhs-06 & 25 & 20 & 20 & 65 \\
\hline 7 & Mhs-07 & 25 & 45 & 25 & 95 \\
\hline 8 & Mhs-08 & 25 & 40 & 25 & 90 \\
\hline 9 & Mhs-09 & 25 & 38 & 25 & 88 \\
\hline 10 & Mhs-10 & 25 & 41 & 25 & 91 \\
\hline 11 & Mhs-11 & 25 & 31 & 25 & 81 \\
\hline 12 & Mhs-12 & 20 & 34 & 20 & 74 \\
\hline 13 & Mhs-13 & 25 & 40 & 25 & 90 \\
\hline 14 & Mhs-14 & 25 & 0 & 0 & 25 \\
\hline 15 & Mhs-15 & 25 & 35 & 20 & 80 \\
\hline 16 & Mhs-16 & 25 & 40 & 25 & 90 \\
\hline 17 & Mhs-17 & 25 & 30 & 0 & 55 \\
\hline 18 & Mhs-18 & 20 & 25 & 10 & 55 \\
\hline 19 & Mhs-19 & 25 & 35 & 20 & 80 \\
\hline 20 & Mhs-20 & 25 & 25 & 20 & 70 \\
\hline 21 & Mhs-21 & 20 & 20 & 10 & 60 \\
\hline 22 & Mhs-22 & 20 & 30 & 20 & 70 \\
\hline 23 & Mhs-23 & 20 & 28 & 0 & 48 \\
\hline
\end{tabular}


Histogram: Jurnal Pendidikan Matematika, 4 (2), 2020 - 533

Rusmining $^{1^{*}}$

\begin{tabular}{llcccc}
\hline No & Mahasiswa & $\begin{array}{c}\text { Kemampuan } \\
\text { Merumuskan } \\
\text { Masalah }\end{array}$ & $\begin{array}{c}\text { Kemampuan } \\
\text { Menggunakan Fakta, } \\
\text { Konsep, Prosedur, } \\
\text { Penalaran }\end{array}$ & $\begin{array}{c}\text { Kemampuan } \\
\text { Menafsirkan } \\
\text { Hasil }\end{array}$ & Nilai \\
\hline 24 & Mhs-24 & 25 & 20 & 20 & 65 \\
\hline 25 & Mhs-25 & 25 & 30 & 15 & 70 \\
\hline 26 & Mhs-26 & 25 & 45 & 17 & 87 \\
\hline 27 & Mhs-27 & 25 & 45 & 25 & 95 \\
\hline 28 & Mhs-28 & 25 & 40 & 15 & 78 \\
\hline 29 & Mhs-29 & 25 & 38 & 0 & 60 \\
\hline 30 & Mhs-30 & 20 & 40 & 15,73 & 70,03 \\
\hline & Rata-rata & 23,33 & 30,63 & & \\
\hline
\end{tabular}

(Sumber: Data Primer, Tahun: 2020)

Berdasarkan hasil belajar yang disajikan pada Tabel 1 tersebut, maka dapat diuraikan hasil serta pembahasan sebagai berikut:

1. Diperoleh nilai rata-rata kemampuan proses literasi matematika sebesar 70,03 dari nilai maksimal 100, artinya kemampuan hasil belajar secara keseluruhan mahasiswa masih berada pada level baik.

2. Skor rata-rata kemampuan merumuskan masalah sebesar 23,33 dari skor maksimal 25 artinya mahasiswa sudah baik dalam merumuskan masalah yang disajikan pada soal. Mahasiswa sudah mampu memahami permasalahan dengan menuliskan apa yang diketahui dan ditanyakan pada soal. Berikut ini salah salah satu contoh hasil pekerjaan mahasiswa yang tidak mampu merumuskan masalah. Dari Gambar 1 di bawah ini, tampak bahwa mahasiswa tidak mampu merumuskan masalah saat hendak membuktikan aksioma ke tiga ruang vektor. 
Histogram: Jurnal Pendidikan Matematika, 4 (2), 2020 - 534

Rusmining $^{1^{*}}$

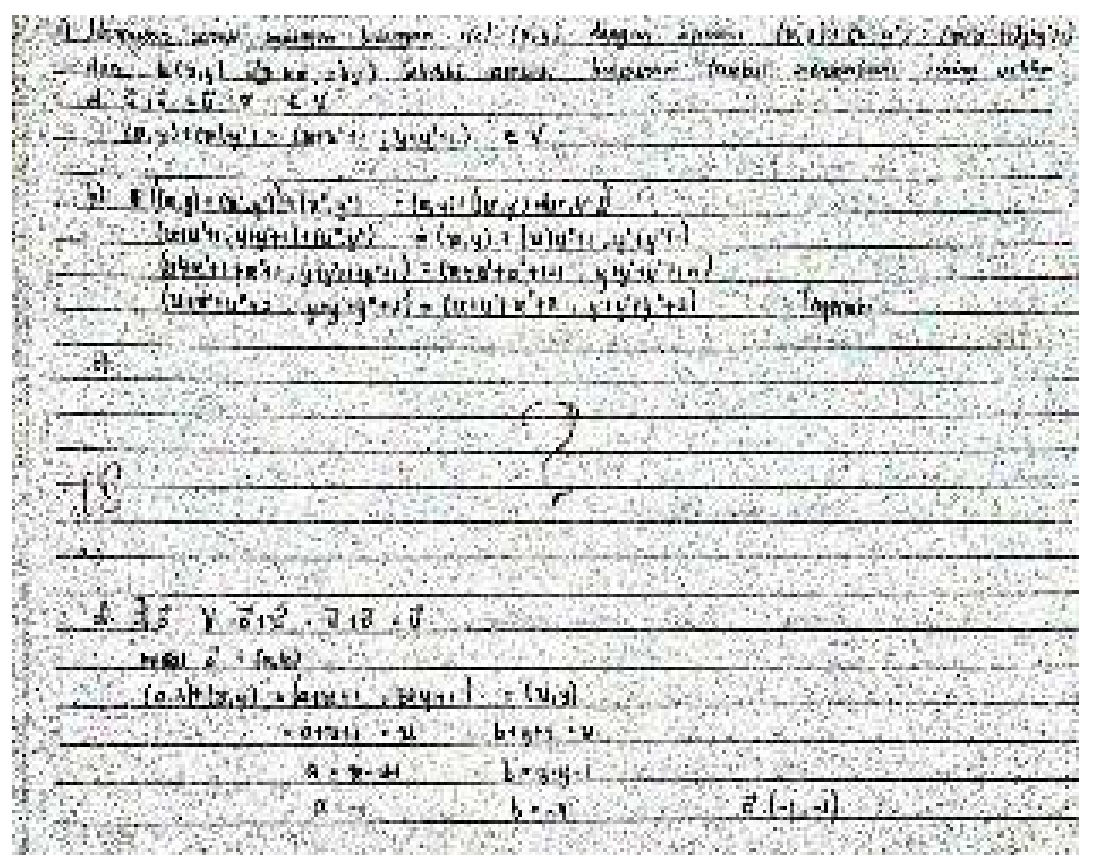

Gambar 1. Contoh Ketidakmampuan Merumuskan Masalah

3. Skor rata-rata kemampuan menggunakan fakta, konsep, prosedur dan penalaran mendapatkan skor 30,63 dari skor maksimal 50 artinya mahasiswa belum sepenuhnya mampu menggunakan kemampuan konsep, prosedur dengan baik. Sebagian besar mahasiswa belum mampu membuat strategi pemecahan masalah, hal ini terbukti kemampuan penalaran dan pemecahan masalah belum tampak maksimal. Mahasiswa masih kesulitan dalam upaya membuktikan sepuluh aksioma ruang vektor yang runtut. Sebagian mahasiswa mampu membuktikan secara runtut, tetapi sebagian yang lain belum mampu membuktikan secara tuntas. Bahkan ada dua mahasiswa yang tidak mampu sama sekali untuk melakukan kemampuan menggunakan fakta, konsep, prosedur dan penalaran. Gambar 2 berikut ini merupakan contoh ketidakmampuan dalam menggunakan konsep, fakta, prosedur dan penalaran.

4. Skor rata-rata kemampuan menafsirkan hasil sebesar 15,73 dari skor maksimal 25 artinya mahasiswa belum sepenuhnya mampu menafsirkan dan mengevaluasi hasil pekerjaannya dengan baik. Hal ini akibat dari kesalahan saat mengolah kemampuan fakta, konsep, prosedur dan penalaran yang belum sempurna. Akibatnya berdampak pada kesalahan saat membuat tafsiran dan kesimpulan dari permasalahan. Bahkan ada enam mahasiswa yang tidak mampu sama sekali untuk membuat tafsiran hasil yang telah didapatkan. Gambar 3 berikut merupakan contoh kesalahan mahasiswa saat melakukan tafsiran atau evaluasi dari hasil yang telah diperoleh. 
Histogram: Jurnal Pendidikan Matematika, 4 (2), 2020 - 535

Rusmining $^{1^{*}}$

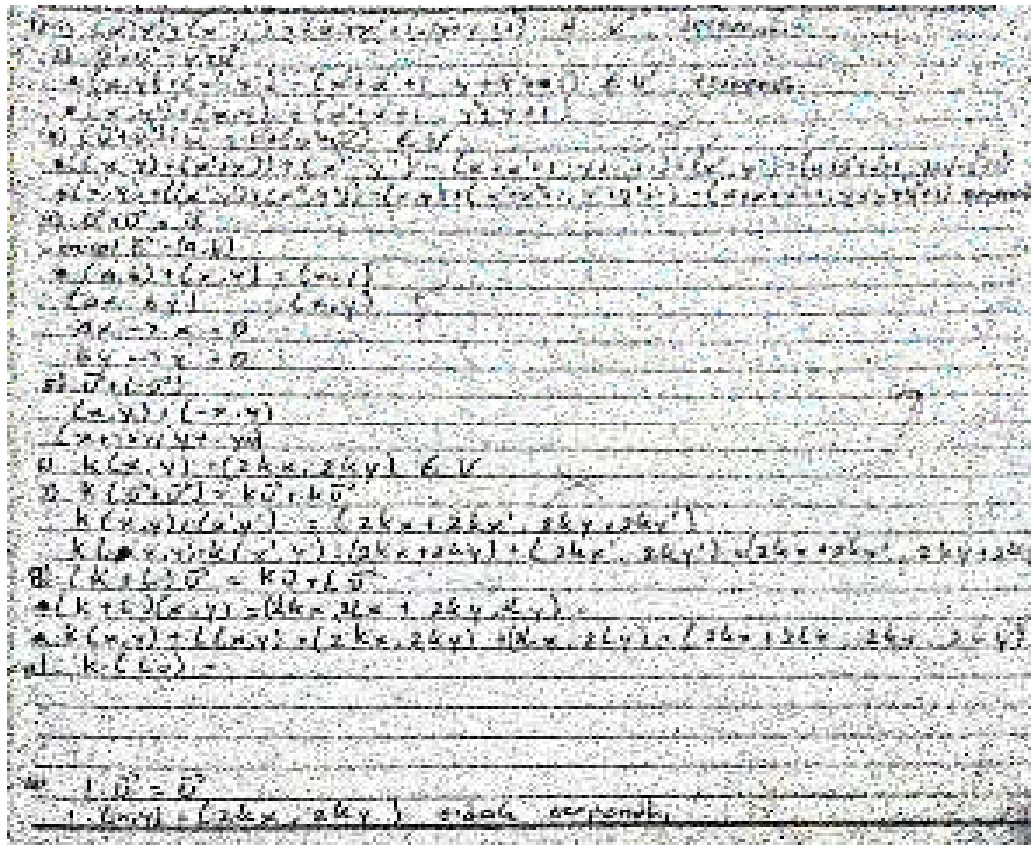

Gambar 2. Contoh Ketidakmampuan Menggunakan Konsep, Fakta, Prosedur dan Penalaran

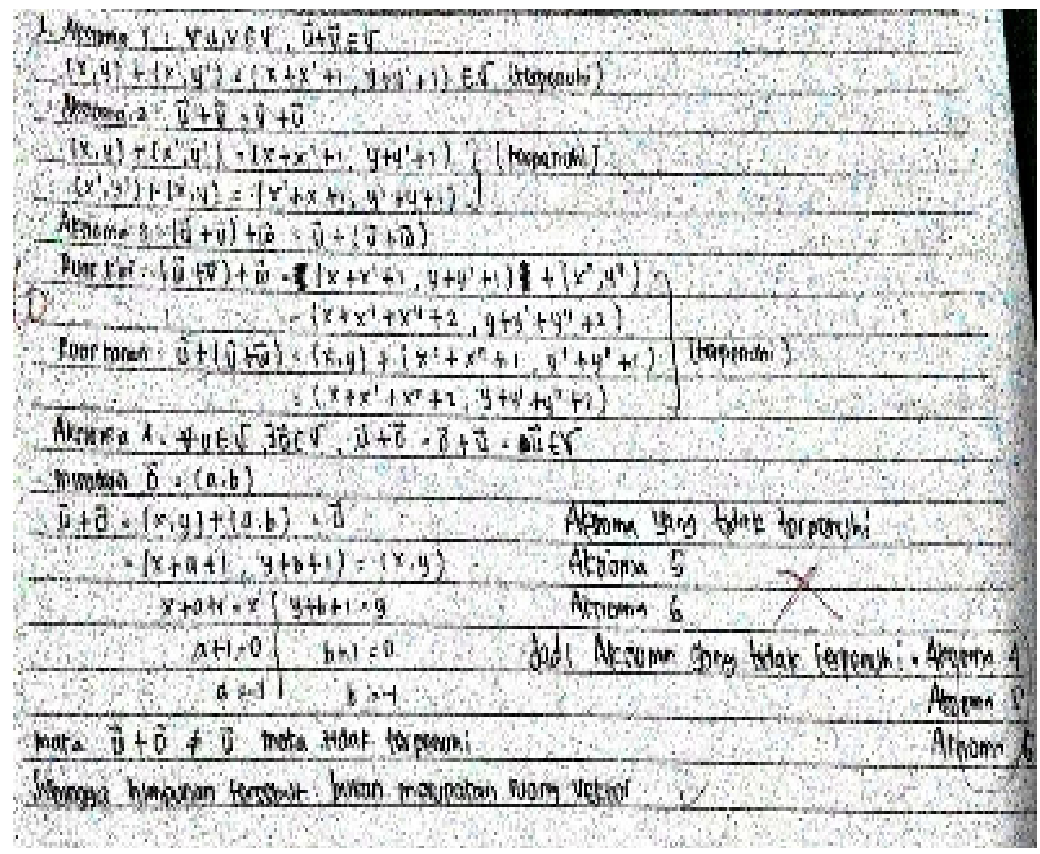

Gambar 3. Contoh Kesalahan Menafsirkan Hasil

Diagram tentang analisis hasil belajar matematika dilihat dari komponen proses literasi matematika disajikan ke dalam Gambar 4 berikut. 
Histogram: Jurnal Pendidikan Matematika, 4 (2), 2020 - 536

Rusmining $^{1^{*}}$

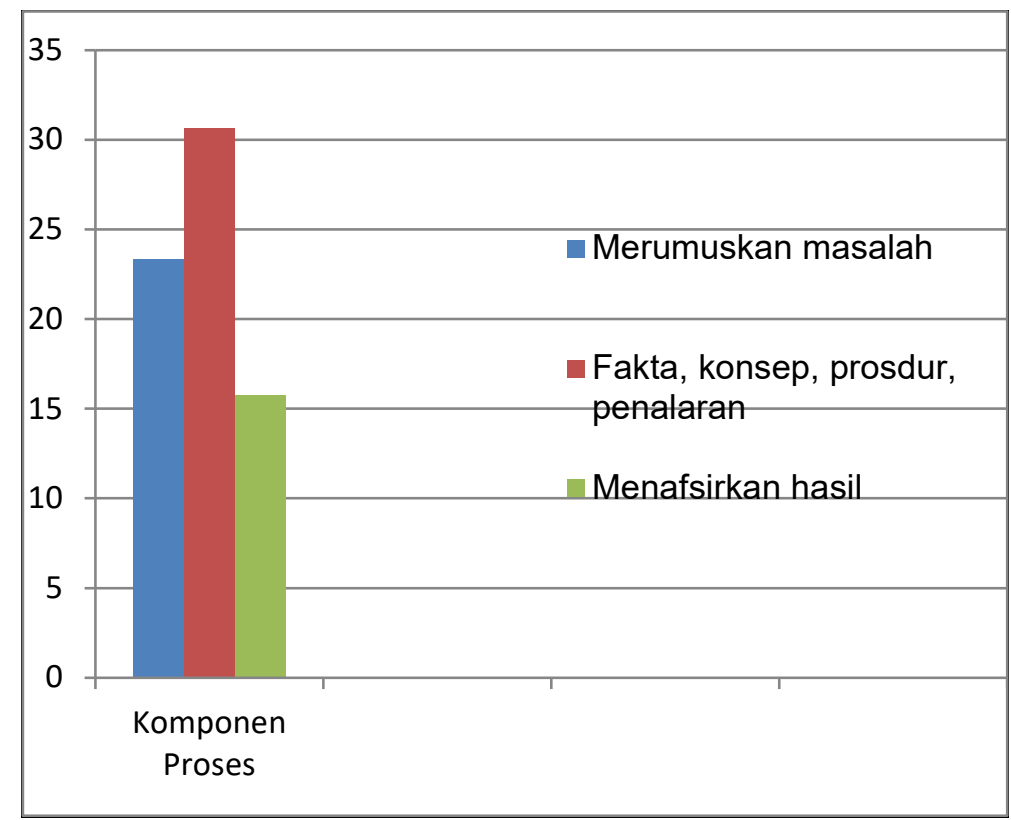

Gambar 4. Komponen Proses Literasi Matematika

Berdasarkan Gambar 4 di atas tampak bahwa kemampuan merumuskan masalah lebih menonjol dibandingkan kemampuan menafsirkan hasil. Secara umum, mahasiswa telah mampu membuat rumusan masalah dengan benar, akan tetapi kemampuan menggunakan fakta, konsep, prosedur dan penalaran masih kurang baik.

\section{KESIMPULAN DAN SARAN}

\section{A. Kesimpulan}

Berdasarkan uraian pada bagian hasil penelitian dan pembahasan yang telah diuraikan, maka dapat disimpulkan antara lain. 1) Kemampuan literasi dilihat dari proses merumuskan masalah memperoleh skor rata-rata 23,33 dari skor maksimal 25 artinya mahasiswa sudah baik dalam merumuskan masalah yang disajikan pada soal. 2) Kemampuan literasi dilihat dari proses menggunakan konsep, fakta, prosedur dan penalaran mendapatkan skor rata-rata 30,63 dari skor maksimal 50 artinya mahasiswa belum sepenuhnya mampu menggunakan kemampuan konsep, prosedur dengan baik. 3) Kemampuan literasi dilihat dari proses melakukan penafsiran hasil mendapatkan skor rata-rata 15,73 dari skor maksimal 25 artinya mahasiswa belum sepenuhnya mampu menafsirkan dan mengevaluasi hasil pekerjaannya dengan benar. Dari ketiga komponen proses tersebut, dapat dikatakan bahwa kemampuan merumuskan masalah paling 
Histogram: Jurnal Pendidikan Matematika, 4 (2), 2020 - 537

Rusmining $^{1^{*}}$

menonjol dibandingkan kemampuan menggunakan fakta, konsep, prosedur, dan penalaran serta kemampuan menafsirkan hasil yang diperoleh.

\section{B. Saran}

Dari hasil penelitian ini, dihasilkan saran diantaranya perlu mengembangkan sebuah perangkat pembelajaran yang berbasis pada literasi matematika, baik dari segi komponen proses, komponen konten, dan konteks literasi matematika.

\section{DAFTARPUSTAKA}

Ojose, B. (2011). "Mathematics Literacy: Are We Able To Put The Mathematics We Learn Into Everiday Use?". Journal of Mathematics Education, Vol. 4 No.1 Hal. 89100.

Draper, R. J. (2002). "School Mathematics Reform, Constructivism, and Literacy: A Case for Literacy Instruction in The Reform-Oriented Math Classroom". Journal of Adolescent \& Adult Literacy, Vol. 46 No. 6.

Wong, P. (2005). "Mathematical Literacy of Hong Kong's 15 Year Old Students in PISA". Education Journal, Vol. 32 No. 1.

Brewley, D. S. (2012). "College Mathematics Literacy Workers of The Young People's Project Chicago: A Community of Practice". Journal of Urban Mathematics Education, Vol. 5 No. 1 Hal. 44-54.

OECD. (2010). The Programme for International Student Assessment (PISA). http://www.oecd.org/dataoecd/61/15/46241909.pdf.

Lasati, D. (2007). "Penerapan Pendekatan Konstruktivisme pada Pembelajaran Teorema Phytagoras di Kelas 8 SMP”. Jurnal Pendidikan Inovatif, Vol. 3 No.1 Hal. 47-50.

Rusmining. (2014). Analysis of Mathematics Literacy, Learning Constructivism and Character Education. International Journal of Education and Research, Vol.2 Hal. 331.

Rusmining. (2019). "Penerapan Think Pair Share Bermuatan Literasi Matematika Untuk Meningkatkan Kemampuan Komunikasi Matematika". HISTOGRAM: Jurnal Pendidikan Matematika, 3(2), Hal. 98-107.

Sugiyono. (2010). Metode Penelitian Pendidikan, Pendekatan Kuantitatif, Kualitatif, dan $R \& D$. Bandung: Alfabeta. 